\title{
Multiplex RT-PCR for detection and identification of three necroviruses that infect olive trees
}

\author{
Print E-mail Add to Marked List Save to EndNoteWeb. \\ Serviços $9^{\circ}$ an Save to EndNote, RefMan, ProCite more options
}

Author(s): Varanda C (Varanda, Carla) ${ }^{1,2}$, Cardoso JMS (Cardoso, Joana M. S.) $)^{1,3}$, Felix MD (Felix, Maria do Rosario) $)^{1,2}$, Oliveira S (Oliveira, Solange) $)^{1,3}$, Clara MI (Clara, Maria Ivone) $)^{1,2}$

Source: EUROPEAN JOURNAL OF PLANT PATHOLOGY Volume: 127 Issue: 2 Pages: 161164 Published: JUN 2010

\section{Times Cited: 0 References: 14 EXCitation Map}

Abstract: An optimized multiplex RT-PCR assay was developed to discriminate three necrovirus (Olive latent virus 1 (OLV-1), Tobacco necrosis virus D (TNV-D) and Olive mild mosaic virus (OMMV)) that infect olive trees. An olive orchard consisting of 54 trees of cv. "Galega vulgar" in the south of Portugal was surveyed. dsRNA fraction was used as template and revealed the 3 viruses, singly or in multiple infections, present in 17 out of 54 trees in the orchard. OMMV was the most frequent occurring in 15 trees, followed by OLV-1 in 12 and TNV-D in 4 plants. The results obtained showed that necrovirus- specific dsRNAs do exist in infected tissues in amounts below the resolution permitted by gel electrophoresis analysis and that the developed multiplex PCR based assay is of much higher sensitivity. The design of the specific primers described enabled, for the first time, to discriminate between OMMV and TNV-D by means of RT-PCR assays, an indispensable tool in identification, epidemiology and survey studies.

Document Type: Article

Language: English

Author Keywords: Multiplex RT-PCR; Olive necrovirus; Primer design; Viral detection

KeyWords Plus: COMPLETE GENOME SEQUENCE; VIRUS-D ISOLATE; OLEA-EUROPAEA L

Reprint Address: Varanda, C (reprint author), Univ Evora, Inst Ciencias Agr \& Ambientais Mediterran, P7002554 Evora, Portugal

Addresses:

1. Univ Evora, Inst Ciencias Agr \& Ambientais Mediterran, P-7002554 Evora, Portugal

2. Univ Evora, Dept Fitotecnia, P-7002554 Evora, Portugal

3. Univ Evora, Dept Biol, P-7002554 Evora, Portugal

E-mail Addresses: carlavaranda@uevora.pt 